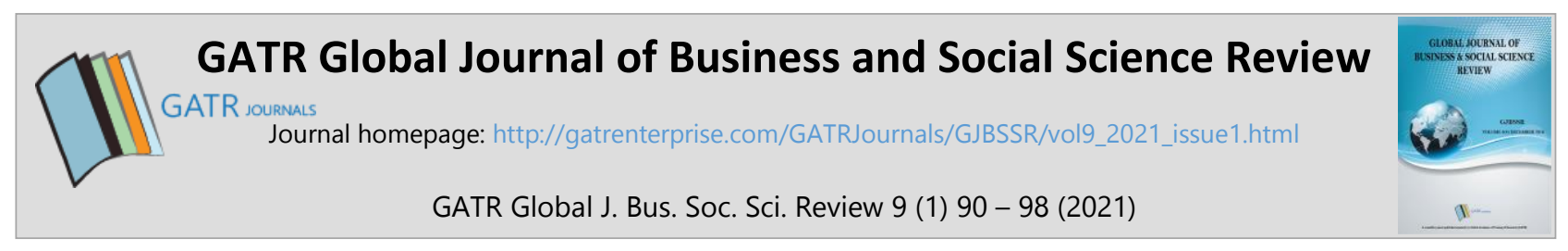

\title{
Business Continuity of MSMEs in Small Island Facing the Covid-19 Pandemic
}

\author{
Ayu Krishna Yuliawati ${ }^{*}$, Rofi Rofaida ${ }^{1}$, Budhi Pamungkas Gautama ${ }^{1}$, \\ Asti Nur Aryanti \\ ${ }^{1}$ Universitas Pendidikan Indonesia, jl Dr. Setiabudhi no.229, 40154, Bandung, Indonesia \\ ${ }^{2}$ Sekolah Tinggi Ilmu Ekonomi Indonesia Membangun (INABA), jl. Soekarno-Hatta no.448, 40266, Bandung, \\ Indonesia
}

\begin{abstract}
Objective - Geopark in Indonesia, especially in Belitong Island, has small and medium enterprises (MSMEs) engaged in various creative industries. The potential for the development of the creative industry for geoproducts is still open to enter the international market. Due to the Covid-19 pandemic, its development still faces several obstacles, where most of the geoproducts are made by MSMEs with limited market access, technology and financial access which results in low quality of products produced, and the level of competition for the domestic market is getting higher, while entering the international market is difficult. This study aims to analyze the impact of Covid-19 on MSME geoproducts in Geopark tourist destinations, and analyze Business Continuity Management at these MSMEs.

Methodology/Technique - The research method used is quantitative and qualitative method, in which descriptive analysis are carried out through online survey and online FGD.

Findings - The results of this study show how MSMEs' in small island of Belitung were severely affected by the Covid19 pandemic. There was a drastic decrease product sales volume, some MSMEs were forced to permanently close their businesses and $47 \%$ of MSMEs decided to temporarily close their businesses until conditions improved. The business income was severely impacted due to the absence of tourists (customer) to the island and the difficulty in obtaining raw materials as production input. MSMEs run business continuity by implementing a pivoting strategy and transformation to digital platform. The roles of the government, private sector, financial institution, academic and geopark managers are needed to help MSMEs survive in times of crisis.
\end{abstract}

Type of Paper: Empirical.

JEL Classification: M1, M10.

Keywords: Business Continuity; Geoproduct; Geopark; Covid-19 Pandemic; Belitong

Reference to this paper should be made as follows: Yuliawati, A.K; Rofaida, R; Gautama, B.P; Aryanti, A.N. (2021). Business Continuity of MSMEs in Small Island Facing the Covid-19 Pandemic, GATR Global J. Bus. Soc. Sci. Review, 9(1): 90 - 98. https://doi.org/10.35609/gjbssr.2021.9.1(10)

\section{Introduction}

Geopark encourages local development and economy through the promotion of good brands related to natural heritage to attract and increase the number of tourist visits.

\footnotetext{
${ }^{*}$ Paper Info: Revised: December 23, 2020

Accepted: March 31, 2021

* Corresponding author: Ayu Krishna Yuliawati

E-mail: ayukrishna@upi.edu

Affiliation: Faculty of Economics and Business Education, Universitas Pendidikan Indoneisa
} 
It is a place an innovation for the protection of natural and geological heritage and plays an important role in the development of geotourism. When developing geotourism, the creation of a geopark can generate new job opportunities, new economic activities and additional sources of income, especially in rural areas. This encourages the production of local products and local handicrafts involved in geotourism and geoproducts (Farsani et. al. 2010). MSMEs are an important community in Belitong Geopark Indonesia, and plays an important role, both as suppliers and providers of products/services for geotourism activities and as a driver of local economy.

The Covid-19 pandemic is a disaster that has had a devastating impact on business operation and viability. In Indonesia, the policy that taken by government is large-scale social restrictions (through school from home, closure of tourist attractions and entertainment, offices are urged that employees work at home, as well as other restrictions aimed at severing the chain of the spread of Covid-19) (Muhyiddin \& Wardhana, 2020).

When the tourism sector has come to a halt like in the small island of Belitung, all of its activities involving local MSMEs have come to a standstill. MSMEs stopped producing their product/services, because no customers have come in to buy their product/services. In Indonesia where MSMEs play a leading role in the nation's economy with a multiplier effect, the pandemic severely impacted MSMEs, especially in small islands that rely on tourists visits. There is a potential market for tourism products/services, MSMEs entrepreneur create value and innovation in order to maintain the sustainability of their business. MSMEs assessed the current situation and made decisions to overcome the situation, rather than waiting for the pandemic to end. From the problems faced, MSMEs were able to identify alternative solutions and maintain business stability.

MSMEs suffered the most as they are relatively resource constrained and less resilient. Most MSMEs also do not have an understanding of business management, such as financial management, human resources, marketing and business risk management. Most small businesses are also characterized by informality, which limits SMEs access to risk management mechanisms (ESCAP, 2013). Thus, this study aims to analyze the impact of Covid-19 on MSMEs' producing geoproducts in small Island of Belitung Indonesia and examine Business Continuity Management practices within MSMEs.

\section{Literature Review}

MSMEs are local producers of geoproduct in geoparks. They work together with geopark managers to develop and market these products and services, thus contributing to the local economic development of the area. Geoproducts are not only in the form of handicraft products or local food but can also be in the form of geotourism services. Geotouristic products are the composition of geo-products and the concept of tourism. Thus, geotouristic products are tangible and intangible geo-products developed on the basis of abiotic nature, co-created (knowledge and craft) and experienced in connection with trips outside the residence, both before the trip, during its duration, and during the stay of the geotourist and upon return, allowing for fulfilment of geotouristic goals (Dryglas \& Miśkiewicz,2014). Geotourism products and geotourism supply elements are a general concept that aims to meet the needs of tourists and is implemented by one of 5 groups: package geotour organizers, governments, individual geotourism product producers, local communities and tourists themselves (Dryglas,2012).

Due to the nature of their business (which depend on tourism activities and also their own limited resources), MSMEs are vulnerable to sudden events of disaster such as the Covid-19 pandemic. According to James and Wooten (2011), communities have been devastated by natural disasters, extreme acts of violence and terrorism, and the life-threatening pandemic. Crisis is defined as a rare and extreme high impact events and have become the new normal in organizational life. Crisis events can have associated expenses, such as the loss of business, decreases in stock prices, and declines in productivity. When designing a Business Continuity Management Plan, companies seek to meet strategic, operational, and tactical needs. Considerable time and investment is often wasted through a poorly planned, structured, and implemented approach to designing and implementing Business Continuity Management Plans. 
Business continuity can be categorised into 3 main areas: contingency planning crisis management and recovery (Blyth, 2009). According to Cremonini and Samarati, (2008), a business continuity plan is a technical, administrative, and management activities with purpose to plan recovery steps and restore critical business assets after an unforeseen event which have disturbed the functions. Despite the importance of a business continuity plan, Cybulski (2016) found that many business owners do not consider it to be a high priority project for their enterprise. The benefit of such plans especially in return of investment are not realized by entrepreneurs. Improving business continuity and resilience also require the government, the private sector and the local communities to work together. The government defines the policy for managing disaster risks, ensuring adequate infrastructure and investment climate for SMEs to thrive, and provides direct intervention during pre and post-disaster operations according to Ballesteros and Domingo (2015).

Studies conducted on MSMEs, disaster experience and business continuity in other countries, such as in Thailand (Kato \& Charoenrat, 2018), New Zealand, (Hatton, Grimshaw, Vargo \& Seville, 2016) and the United States of America (HP \& Score, 2008), reveal that MSMEs have a low level of preparedness for business continuity, including a failure to put in place a plan, effective leadership in crisis and knowledge in this field is necessary for the business in being able to seize opportunities post-disaster. In America, about $75 \%$ of companies without business continuity plans fail within 3 years of a disaster and companies that are not able to resume operations within 10 days (of a disaster hit) are not likely to survive (Cremonini \& Samarati, 2008). There has been few studies conducted on MSMEs in small islands, particularly in developing countries such as Indonesia.

MSMEs stand out with cases of limited resources which show they are not ready to face a crisis (Brahim, 2020). MSMEs also have no experience in preparing for business continuity, including building organizational resilience in a crisis (Kato, 2018). Businesspeople have not understood much about organizational resilience and business continuity management. Businesspeople need to make effort to obtain information and support from business relations during a crisis. The limited implementation of this organizational resilience shows that MSME businesspeople do not consider this a strategic priority. In the context of MSMEs, business continuity needs to be understood fundamentally so that businesspeople are able to map their ability to respond to crises (Brahim, 2020). Business Continuity knowledge needs to be adjusted to the size of the business, length of effort and disaster experience. In this case, because MSMEs are small in scale, it is not surprising that they are not ready to implement business continuity. This has been demonstrated amidst the current pandemic state, in which many MSMEs have stopped operating (Kato, 2018).

Business continuity is one of the ways organizations anticipate and overcome disruptions, so that the risk of loss is reduced, and business operations can continue (Fani \& Subriadi, 2019). Business Continuity can also reduce business risk due to crisis / disaster and help restore business after a crisis and return it to its previous function (Kato, 2018; Torabi et. al., 2014). Business continuity planning is a strategic approach to minimize loss or damage in the future (Momami, 2010). Business Continuity can improve performance and reputation, which in turn can increase business competitiveness, sustainability and resilience (Kato, 2018).

Business continuity is a management process that identifies potential factors threatening the organization and provides a framework for building resilience and the ability to respond effectively. This response must protect the interests of its key stakeholders, as well as the reputation of the organization, brands and activities that create value. Business continuity is about striking a balance between preparing for situations for which contingency plans must be used. Business continuity and risk assessment techniques are combined in the formation of programs to manage potential crises (Speight, 2011)

Business continuity defines what is essential for organizational survival after a major disaster affecting business activities. Business continuity planning, according Speight (2011), can be viewed as a 4 stage cycle: (a) mitigation: Reducing and managing risk; (b) readiness: Institutionalize all necessary actions, especially planning and warning systems; (c) response: Managing emergencies or crises; (d) recovery: identifying the requirements to return to normal after the incident is over. 
MSMEs must understand why it is necessary to implement business continuity to combat the possibility of unexpected events (incidents, emergencies, disasters, crises). Business continuity is needed to facilitate the continuation of business operations efficiently despite business disruptions (Tammineedi, 2010). Business continuity relies heavily on using a holistic approach. Business continuity is an effort to provide a holistic and socio-technical approach to proactive business management and be able to respond to possible disaster risks (Niemimaa, 2019). The most important component in the recovery strategy is the application of business continuity to reduce the risk that occurs due to a crisis (such as the current pandemic) (Fani \& Subriadi, 2019)

The fundamental stage in implementing business continuity is understanding the products being sold, to understand their strengths and weaknesses, so that if a crisis occurs, we can make strategic decisions (Torabi et. al., 2014). Crisis planning can begin by making a risk management formulation. This condition is closely related to organizational resilience and business continuity (Brahim, 2020). The application of business continuity identifies risk assessments, analyzes results and implements risk mitigation measures at the organizational level. The business continuity strategy approach can help companies to maintain their business by: (1) conducting a risk assessment to reduce the severity of disruptions if a threat occurs, (2) developing emergency response plans so that management acts quickly on an event, so that resources will remain protected (Tammineedi, 2010).

\section{Research Methodology}

This research methodology includes both quantitative and qualitative methods, utilizing descriptive analysis. The main objectives are to assess the impact of Covid-19 on MSMEs and business continuity on the Small Island of Belitung Indonesia. The first phase of the study consists of collecting secondary data of reports, past studies and other documents for literature review. The second phase is sending electronic questionnaires to MESME in Belitung ( $\mathrm{n}=50$ ), but only 30 MSMEs respondent and send back the questionnaires. In the third phase, primary data was obtained through online FGD with MSMEs' owner, local government, integrated small business service centre (PLUT), MSMEs Galery and Belitong Geopark management. In-depth interviews were also conducted to six MSMEs owner, where the main questions are: What is the impact of Covid-19 on your business currently? What are the main problems faced and solutions? Thus, the qualitative data is collected and analysed. The quantitative data is processed through several stages, namely: tabulation, classification, and descriptive analysis.

\section{Results}

\subsection{Impact of Covid-19 on MSME's Small Island of Belitong}

Indonesia declared the Covid-19 pandemic a national emergency and lockdown or social mobility restriction was enforced in several large cities in Java Island including Jakarta. Belitung Island has been impacted by the Covid-19 pandemic, where tourist visit fell drastically between March 2020 to August 2020. This has had an impact on MSMEs in the tourism sector, such as: travel agents, tour-guides, transportation, retail souvenir shops, homestays, handicrafts, food and beverage producers which is part of the tourism value chain. The results of an online survey conducted to Belitung MSMEs' owner showed that $60 \%$ of MSME admitted that their businesses were deeply affected by the Covid-19 pandemic. These businesses are predominantly run as the main source of livelihood for local communities. The impact of this condition is $6 \%$ of MSMEs are forced to permanently close their businesses and 47\% of MSMEs decide to temporarily close their businesses until conditions improve. This pandemic affected the marketing process the most, which was hampered because there were no tourists, and the procurement of raw materials was hard to come by.

In facing this crisis, MSME players need to create online marketing patterns to maintain sales stability. This scheme is still considered commonplace by local MSME actors. Hence, it needs the support of other parties to facilitate this, one of which is the local government. MSMEs need cash assistance for business development 
and entrepreneurship development support. So far, the financial assistance program offered by the government has been difficult to access about 33\% of MSME state this condition. MSMEs need guidance in legalizing their organization status, because $87 \%$ of MSMEs do not have a legal entity, making it difficult to access aid funds. The Covid-19 pandemic required enterprises to make new business plans to gain profits. From the FGD results, it is seen that most MSMEs already have new business plans to deal with the pandemic as they try to make their business survive the current condition. In this process, the search for information on business development is a strategic step to open up new business opportunities (91\%). The new business plan must be communicated to employees, so that businesspeople are also able to motivate their employees to stay enthusiastic. New business planning certainly requires broader cooperation to strengthen networks. Therefore, these MSMEs always expand cooperation with other business actors (64\%), such collaboration including collaborative marketing activities.

During the data collection period, we conducted interviews with Belitung geoproducts MSMEs owners online. The condition of the Covid-19 pandemic presents many obstacles for MSMEs players in running their business. An interview with an MSMEs owner named Ayu Rostiati from Sambal Kak Ros said that "the impact of this pandemic disrupts the supply of raw materials, so that the production process also experiences delays". This condition is much different from before the pandemic, the current situation needs to be dealt with by finding other suppliers so that the production process runs smoothly (Interview with Ayu Rostiati).

Raw material constraints are also felt by some MSME players, the condition of raw materials during the Covid-19 pandemic is becoming more difficult to obtain, even if there is a price offered it becomes expensive (Interview with Fajar Winingsih). There are also MSME actors who think that raw materials are currently becoming scarce because many suppliers go bankrupt or access to raw materials outside the city becomes difficult due to social restrictions (Interview with Nur Cahya). Apart from raw materials, MSMEs have also complained about marketing. MSMEs owners admit that their market reach is very limited, still limited to local the market situated in local Belitung tourist attractions. This is an obstacle because MSME owners cannot market their products during the closure of tourist destinations during the Covid-19 pandemic (Interview with Yanti Yustia).

The temporary closure of tourist sites and restrictions on their activities have caused MSME players around Belitung to consider how to maintain their business, because so far, sales revenue has only been obtained from tourists visiting Belitung (Erwin Wijayanti). The widespread effect of this condition is that the number of sales has decreased drastically, especially for those who are MSMEs in the culinary field. Previously, culinary attractions were the main destination for tourists on vacation in Belitung. However, currently this culinary business must be packaged differently to survive the pandemic (Interview with Sri Mulyati and Erdi Cukro).

The Belitung MSMEs owners finally realized that the impact of the Covid-19 pandemic would last longer than expected, so they couldn't just stand by and wait for the situation to be better. Many MSMEs owner started to design their products offering to penetrate the national market (not only depending on tourists who come to Belitung). They also started to use digital marketing to market their products.

\subsection{Business Continuity Management at Small Island MSMEs}

The online FGD conducted was to discuss about the business continuity management implemented in their enterprises and it is viewed upon 5 stages of business continuity. Stages 1 and 2 are early detection and preparation. Most MSMEs are not able to carry out this stage properly. All MSMEs are of the opinion that a pandemic has an impact on business both in terms of production, finance, human resources, and marketing. All MSMEs know and understand the existence of business risks but have not been able to see signs that this pandemic will have an impact on business. The Covid-19 pandemic is an unpredictable event, global in nature and is fast spreading, MSMEs are unable to predict and prepare themselves if this pandemic extends to Indonesia.

Stage 3: overcoming the crisis. The results show that most MSMEs do not have the ability to accept and manage crises properly. All MSMEs expand and strengthen co-operation with other business actors to

GATR Global J. Bus. Soc. Sci. Review 9 (1) 90 - 98 (2021) 
strengthen business during the COVID 19 pandemic and all MSMEs believe they can overcome business obstacles in the current pandemic era, however the success of leadership practices cannot be determined by the leader alone but must also involve employees. Employee involvement in the leadership process will give moral confidence to employees that they are an important part of the company. If employees already have this kind of confidence, there will be trust in the leader and the employees will give performance above the company's expected performance. Leadership practice by involving employees still needs to be improved because only $50 \%$ of business owners involve employees in the decision-making process. Then only $50 \%$ of business owners provide motivation to employees so that they are always enthusiastic at work. Another aspect that still needs to be improved is the search for the latest information related to business developments during the Covid-19 pandemic, which can be seen in Table 2 .

Table 2. Overcoming the Crisis

\begin{tabular}{|c|c|c|}
\hline Number & Description & Interpretation \\
\hline 1. & Length of effort & $\begin{array}{l}\text { As many as } 44 \% \text { of MSME players have only been running a business } \\
\text { for about } 1-2 \text { years }\end{array}$ \\
\hline 2 & Financial records & $\begin{array}{c}\text { As many as } 67 \% \text { of MSMEs do simple financial records in their } \\
\text { business }\end{array}$ \\
\hline 3. & $\begin{array}{l}\text { Understanding of financial } \\
\text { records }\end{array}$ & $\begin{array}{c}\text { As many as } 78 \% \text { of respondents already understand the process of } \\
\text { recording business finances }\end{array}$ \\
\hline 4. & $\begin{array}{c}\text { Separation of business and } \\
\text { personal finances }\end{array}$ & $\begin{array}{l}\text { Only } 33 \% \text { of respondents separate business finances from personal } \\
\text { finances }\end{array}$ \\
\hline 5. & $\begin{array}{l}\text { Reserve finances in the form of } \\
\text { cash }\end{array}$ & $\begin{array}{c}\text { Only } 33 \% \text { of respondents have provided financial backup in the form } \\
\text { of cash. Even though there is, only about } 15 \% \text { of the proportion of } \\
\text { monthly profit is placed into cash }\end{array}$ \\
\hline 6. & Understand business risks & $\begin{array}{l}\text { All respondents understand that every business has risks, especially } \\
\text { financial risks. The existence of the Covid } 19 \text { pandemic is considered to } \\
\text { be very disruptive to business operations. In this condition } 89 \% \text { of } \\
\text { respondents manage the risks that arise }\end{array}$ \\
\hline 7. & $\begin{array}{l}\text { Search for business climate } \\
\text { information }\end{array}$ & $\begin{array}{l}\text { As many as } 50 \% \text { of respondents searched for information about the } \\
\text { business climate such as credit facilities, credit scheduling and other } \\
\text { important information }\end{array}$ \\
\hline
\end{tabular}

Source: Author (2020)

Stage 4 and 5: The recovery and learning stage. MSMEs have taken steps to recover and learn from this crisis. Most MSMEs (89\%) think that this pandemic provides new opportunities for business development. They have a new business plan in dealing with the COVID 19 pandemic so that they can survive and even get a profit $(75 \%)$ and the rest $(25 \%)$ are planning to make a new business plan. All MSMEs agree that this pandemic requires you to learn about new skills in managing a business.

Table 3. The Recovery and Learning Stage

\begin{tabular}{|c|c|c|}
\hline Number & Description & Interpretation \\
\hline 1. & $\begin{array}{l}\text { A new business plan for products to address } \\
\text { Covid-19. }\end{array}$ & $\begin{array}{l}82 \% \text { of respondents made a new business plan in the } \\
\text { face of a pandemic }\end{array}$ \\
\hline 2. & $\begin{array}{c}\text { Seek information about business developments } \\
\text { during the pandemic and socialize it to } \\
\text { employees }\end{array}$ & $\begin{array}{l}91 \% \text { of respondents always searched for business } \\
\text { information during the pandemic and socialized it to } \\
\text { their employees }\end{array}$ \\
\hline 3. & Provide motivation to employees & $\begin{array}{l}\text { All respondents always provide motivation so that } \\
\text { employees are enthusiastic about working }\end{array}$ \\
\hline 4. & $\begin{array}{l}\text { Expanding cooperation with other business } \\
\text { actors to strengthen business during the } \\
\text { pandemic }\end{array}$ & $\begin{array}{l}64 \% \text { of respondents always expand their cooperation } \\
\text { to strengthen their business during the pandemic }\end{array}$ \\
\hline
\end{tabular}

Source: Author (2020) 
The Covid-19 pandemic has impacted almost all business sectors. MSMEs owners have designed new business plans and pivoted their current offering to obtain profits. During this pivoting process, searching for information on business development during a pandemic is a strategic step to open up new business opportunities. The business plan must be communicated to employees, so that business owners are able to motivate their employees to be enthusiastic. New business planning certainly requires broader co-operation to strengthen networks. Therefore, these business owners always expand their co-operation with other business owners and stakeholders.

\section{Discussions}

The study found MSMEs in small island of Belitung uses the passive nature of business continuity management. The MSMEs prior to the disaster did not or had not prepared emergency operational plans to deal with disasters. Before the pandemic, MSMEs ran their business without making any emergency plans or business sustainability plans before the Covid-19 pandemic. The business plan they are running is purely a business plan to operate in normal conditions and in preparing the plan does not consider the risk of natural or man-made disasters to their business. Sapateiro, Baloian, Antunes and Alarcon (2011) state that during crises, organizational failures are rooted due to lack of collective awareness about current condition, communication and management problems. The increasing level of shared situational awareness is a fundamental requirement for Business Continuity Management.

When the Covid-19 pandemic occurred, MSMEs responded by re-thinking how to conduct their business. The situation requires MSMEs to quickly respond to changes in business operations and product/service offering. The number of sales through offline stores have dropped dramatically to $80 \%$ between March 2020 and September 2020, and there is a shortage of raw materials and packaging originating from outside the island. MSMEs responded by entering online marketplaces and starting to promote their products using social media, marketing outside of the island. Then, the MSMEs began to consider how they could recover. MSMEs begin to design strategies, including by making new products that are relevant to market needs, modifying their old products and more. Eggers (2020) suggests that MSMEs have more flexible decision-making processes and closeness to their customer base in a time of crisis and can create more market opportunities when addressed with innovativeness and creativity. MSMEs then began to adapt to new conditions and regulations such as the CHSE (Cleanliness, Health, Safety and Environment) rules, especially MSMEs in the tourism service sector such as hotels, homestays, restaurants, travel, and tourist destinations.

\section{Conclusion}

MSMEs on the small island of Belitung have been greatly impacted by the Covid-19 pandemic; sales have plummeted, consumer behavior has changed, and cash flow has significant decreased. Despite these conditions, MSMEs have adapted to the current situation and achieved business continuity management. They understand the current situation and the causes of the disaster and have begun thinking about how to reduce the risk or minimize the impact of crises on their business. Mitigation is carried out in the form of self-protection, employees and customers from contracting the Covid-19 virus by implementing strict health protocols. MSMEs have changed the Standard Operating Procedures for their service business, for example to comply with the Covid-19 protocols and have begun to formulate action plans to deal with disaster and begin the recovery process. Their business plans have been revised to include disaster risk factors wherein their business practice adopts scenarios of what can be implemented in a crisis situation. Pivoting their product/service offering to current customer demand and opening online channels can help their business survive and recover quickly after a disaster. The ability for MSMEs to respond quickly can only be achieved if the enterprise has a business continuity management plan, therefore MSMEs need support from local government, the private sector and financial institutions to be able to develop, implement and evaluate their business continuity 
management plan. This study has limitations on the sample size used. For further research it is recommended to use a larger sample size with a wider research locus.

\section{Acknowledgements}

The research is funded by the Indonesian Ministry of Research and Higher Education and collaborations for data collection with PLUT Belitung and Unesco Global Geopark Belitong.

\section{References}

Blyth, M. (2009). Business continuity management: building an effective incident management plan. John Wiley \& Sons. Herbane, B. (2020). Locational Contiguity and Business Continuity: Perceived Organizational Resilience of Small-and Medium-Sized Enterprises in UK Business Parks. SAGE Open, 10(2), 2158244020927417. DOI: https// $10.1177 / 2158244020927417$

Cybulski, G. T. (2016). Business Continuity Management: Return on Investment. Aon Global Risk Consulting Dahlhamer,

Dowling, R., Allan, M., \& Grünert, N. (2021). Geological Tourist Tribes. In Consumer Tribes in Tourism (pp. 119-136). Springer, Singapore. https://doi.org/10.1007/978-981-15-7150-3_9

Dryglas, D. (2013). Spa and wellness tourism as a spatially determined product of health resorts in Poland. Current Issues of Tourism Research, 2(2), 30-38.DOI: https://doi.org/10.1515/cjot-2017-0004

Dryglas, D., \& Miśkiewicz, K. (2014). Construction of the geotourism product structure on the example of Poland. In 14th International Multidisciplinary Scientific GeoConference SGEM 2014 (pp. 155-162). DOI: https://doi.org/10.5593/SGEM2014/B52/S20.021

Eggers, F. (2020). Masters of disasters? Challenges and opportunities for SMEs in times of crisis. Journal of Business Research, 116, 199-208. DOI: https://doi.org/10.1016/j.jbusres.2020.05.025

ESCAP 2013. "Building Resilience to Natural Disasters and Major Economic Crises".

Fani, S. V., \& Subriadi, A. P. (2019). Business continuity plan: examining of multi-usable framework. Procedia Computer Science, 161, 275-282. DOI: 10.1016/j.procs.2019.11.124

Farsani, NT, Coelho, CELESTE, \& Costa, C. (2010). Geoparks as art museums for geotourists. Revista Turismo \& Desenvolvimento , 2 (13/14), 567-576. DOI: https://doi.org/10.34624/rtd.v2i13/14.12191

Hatton, T., Grimshaw, E., Vargo, J., \& Seville, E. (2016). Lessons from disaster: Creating a business continuity plan that really works. Journal of business continuity \& emergency planning, 10(1), 84-92.

HP, \& Score. (2008). Impact on U.S. Small Business of Natural \& Man-Made Disasters. Compilation of public and private sector.

James, E. H., \& Wooten, L. P. (2011). Crisis leadership and why it matters. The European Financial Review, 61.

Kato, M., \& Charoenrat, T. (2018). Business continuity management of small and medium sized enterprises: Evidence from Thailand. International journal of disaster risk reduction, 27, 577-587. DOI: https://doi.org/10.1016/J.IJDRR.2017.10.002

Momani, N. M. (2010). Business continuity planning: Are we prepared for future disasters. American Journal of Economics and Business Administration, 2(3), 272.DOI: 10.3844/ajebasp.2010.272.279

Muhyiddin, M., \& Wardhana, D. (2020). Covid-19 Outbreak and Development Planning in Indonesia. Jurnal Perencanaan Pembangunan: The Indonesian Journal of Development Planning, 4(1). DOI: https://doi.org/10.36574/jpp.v4i1.108

Niemimaa, M., Järveläinen, J., Heikkilä, M., \& Heikkilä, J. (2019). Business continuity of business models: Evaluating the resilience of business models for contingencies. International Journal of Information Management, 49, 208-216.DOI: https://10.1016/j.ijinfomgt.2019.04.010

Sapateiro, C., Baloian Tataryan, N., Antunes, P., \& Zurita Alarcón, G. (2011). Developing a mobile collaborative tool for business continuity management.

Speight, P. (2011). Business continuity. Journal of applied security research, 6(4), 529-554. DOI: https// $10.1080 / 19361610.2011 .604021$

Tammineedi, R. L. (2010). Business continuity management: A standards-based approach. Information Security Journal: A Global Perspective, 19(1), 36-50. DOI: https//10.1080/19393550903551843

Torabi, S. A., Soufi, H. R., \& Sahebjamnia, N. (2014). A new framework for business impact analysis in business continuity management (with a case study). Safety Science, 68, 309-323.DOI: https// 10.1016/j.ssci.2014.04.017

GATR Global J. Bus. Soc. Sci. Review 9 (1) 90 - 98 (2021) 
***Interview with Ayu Rostiati (SME's Belitung), 12/08/2020

***Interview with Nur Cahya (SME's Belitung), 12/08/2020

*** Interview with Yanti Yustia (SME's Belitung), 12/08/2020

***Interview with Erwin Wijayanti (SME's Belitung), 12/08/2020

***Interview with Sri Mulyati (SME's Belitung), 12/08/2020

***Interview with Erdi Cukro (SME's Belitung), 12/08/2020 